\title{
Review Article \\ Oxidative Stress and Inflammation: What Polyphenols Can Do for Us?
}

\author{
Tarique Hussain, ${ }^{1,2}$ Bie Tan, ${ }^{1,3}$ Yulong Yin, $^{1}$ Francois Blachier, ${ }^{4}$ \\ Myrlene C. B. Tossou, ${ }^{1,2}$ and Najma Rahu ${ }^{5}$ \\ ${ }^{1}$ Key Laboratory of Agroecological Processes in Subtropical Region, Institute of Subtropical Agriculture, Chinese Academy of Sciences, \\ Observation and Experiment Station of Animal Nutrition and Feed Science in South-Central China, Ministry of Agriculture, \\ Hunan Provincial Engineering Research Center for Healthy Livestock and Poultry Production, Changsha, Hunan 410125, China \\ ${ }^{2}$ University of the Chinese Academy of Sciences, Beijing 10008, China \\ ${ }^{3}$ Hunan Collaborative Innovation Center for Utilization of Botanical Functional Ingredients and Hunan Collaborative \\ Innovation Center of Animal Production Safety, Changsha, Hunan 410000, China \\ ${ }^{4}$ UMR 914 INRA/Agro Paris Tech, Nutrition Physiology and Ingestive Behavior, Paris, France \\ ${ }^{5}$ Department of Veterinary Microbiology, Faculty of Animal Husbandry and Veterinary Sciences, Sindh Agriculture University, \\ Tandojam, Sindh 70050, Pakistan
}

Correspondence should be addressed to Bie Tan; bietan@isa.ac.cn

Received 18 March 2016; Revised 16 August 2016; Accepted 21 August 2016

Academic Editor: Vasantha Rupasinghe

Copyright (c) 2016 Tarique Hussain et al. This is an open access article distributed under the Creative Commons Attribution License, which permits unrestricted use, distribution, and reproduction in any medium, provided the original work is properly cited.

\begin{abstract}
Oxidative stress is viewed as an imbalance between the production of reactive oxygen species (ROS) and their elimination by protective mechanisms, which can lead to chronic inflammation. Oxidative stress can activate a variety of transcription factors, which lead to the differential expression of some genes involved in inflammatory pathways. The inflammation triggered by oxidative stress is the cause of many chronic diseases. Polyphenols have been proposed to be useful as adjuvant therapy for their potential antiinflammatory effect, associated with antioxidant activity, and inhibition of enzymes involved in the production of eicosanoids. This review aims at exploring the properties of polyphenols in anti-inflammation and oxidation and the mechanisms of polyphenols inhibiting molecular signaling pathways which are activated by oxidative stress, as well as the possible roles of polyphenols in inflammation-mediated chronic disorders. Such data can be helpful for the development of future antioxidant therapeutics and new anti-inflammatory drugs.
\end{abstract}

\section{Introduction}

Oxidative stress refers to the excessive production of reactive oxygen species (ROS) in the cells and tissues and antioxidant system cannot be able to neutralize them. Imbalance in this protective mechanism can lead to the damage of cellular molecules such as DNA, proteins, and lipids [1]. Reactive oxygen species are normally produced within the body in limited quantity and are important compounds involved in the regulation of processes involving the maintaining of cell homeostasis and functions such as signal transduction, gene expression, and activation of receptors [2]. Mitochondrial oxidative metabolism in cells produces ROS species and organic peroxides in the process of cell respiration [3]. In addition, in hypoxic conditions, nitric oxide may also be produced during the respiratory chain reaction [4]. This latter reactive nitrogen species (RNS) may further lead to the production of reactive species such as reactive aldehydes, malondioaldehyde, and 4-hydroxynonenal [5]. Main targets of oxidative stress are proteins, lipids, and DNA/RNA, and modifications in these molecules may increase the chances of mutagenesis. ROS/RNS overproduction notably over a prolonged period of time can cause damage of the cellular structure and functions and may induce somatic mutations and preneoplastic and neoplastic transformations. Then, excessive production of ROS in cells and tissues may be deleterious if not removed quickly [6]. Indeed, excessive ROS/RNS production may cause irreversible damage to cells 
resulting in cell death by the necrotic and apoptotic processes [7].

Polyphenols are natural compounds present in plants with numerous biological activities. Phenolic compounds and flavonoids can interact with ROS/RNS and thus terminate chain reaction before cell viability is seriously affected [21].

Various inflammatory stimuli such as excessive ROS/RNS produced in the process of oxidative metabolism and some natural or artificial chemicals have been reported to initiate the inflammatory process resulting in synthesis and secretion of proinflammatory cytokines. Activation of nuclear factorkappa $\mathrm{B} /$ active protein-1 (NF- $\kappa \mathrm{B} / \mathrm{AP}-1)$ and production of tumor necrosis factor-alpha (TNF- $\alpha$ ) have been for instance documented to play critical role in the inflammatory process resulting in several chronic diseases. Phytochemicals such as polyphenols have been reported to be able to modulate the inflammatory processes [22].

This review paper was designed to highlight the biological effects of the polyphenols and their potential to act as compounds with anti-inflammatory properties.

\section{Relationships between Oxidative Stress and Inflammation}

Inflammation is a natural defense mechanism against pathogens and it is associated with many pathogenic diseases such as microbial and viral infections, exposure to allergens, radiation and toxic chemicals, autoimmune and chronic diseases, obesity, consumption of alcohol, tobacco use, and a high-calorie diet. Many of chronic diseases linked with higher production of ROS result in oxidative stress and variety of protein oxidations [23]. Furthermore, protein oxidations turn into release of inflammatory signals molecules and peroxiredoxin 2 (PRDX2) has been recognized as an inflammatory signal [24].

Relationship between oxidative stress and inflammation has been documented by many authors. Evidences indicated that oxidative stress plays a pathogenic role in chronic inflammatory diseases. Damage of oxidative stress such as oxidized proteins, glycated products, and lipid peroxidation results in neuron degenerations mostly reported in brain disorders [25]. ROS generated in brain tissues can modulate synaptic and nonsynaptic communication between neurons that result in neuroinflammation and cell death and then in neurodegeneration and memory loss [25].

Tripeptide glutathione $(\mathrm{GSH})$ is an intracellular thiol antioxidant; lower level of this GSH causes higher ROS production, which results in imbalanced immune response, inflammation, and susceptibility to infection [26]. Study was conducted on the role of GSH and its oxidized form and their regulatory function and gene expressions beyond free radical scavenging activities linked with GSH. GSH takes part in the redox regulation of immunity [27] through mixed disulfides between protein cysteines and glutathiones; it is known as glutathionylation which operates signaling proteins and transcription factors [28].

Inflammatory stimuli induce the release of PRDX2, a ubiquitous redox-active intracellular enzyme. After releasing,

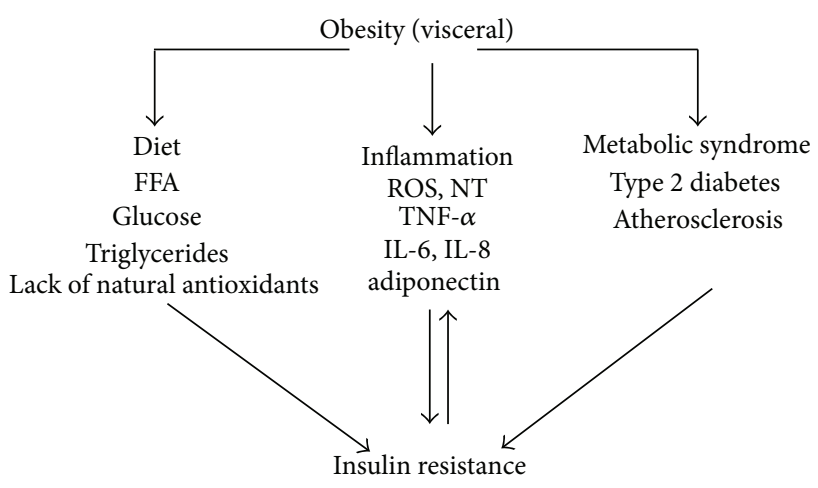

Figure 1: Obesity lifestyle development of chronic diseases through inflammation.

it acts as a redox dependent inflammatory mediator and activates macrophages to produce and release TNF- $\alpha$. Oxidative linked GSH to PRDX2 protein glutathionylation occurs before or during PRDX2 release which regulates immunity. Salzano et al. identified PRDX2 among the glutathionylated proteins released in vitro by LPS-stimulated macrophages using mass spectrometry proteomic methods [24]. In addition, PRDX2 is also the part of inflammatory cascade and can induce TNF- $\alpha$ release. In classical inflammatory response, cytokines are released but PRDX2 does not affect mRNA or protein synthesis mediated by liposaccharide (LPS) although it continuously exists in macrophages but in lowered level when stimulated by LPS then released in oxidized form. This study concluded that PRDX2 and thioredoxin (TRX) from macrophages can alter the redox status of cell surface receptors and allow the induction of inflammatory response, providing a potential novel therapeutic target for chronic inflammatory diseases [24].

Overproduction of oxidative stress induces severe cellular damage of the brain in diabetes [29]. Studies documented that higher lipid peroxidation, nitrite levels, malondialdehyde, and total oxidants status were lower in total antioxidant marker enzymes in the brain of diabetic rats [30]. Moreover, studies demonstrated that diabetes induced oxidative stress increases the level of proinflammatory cytokines such as TNF- $\alpha$ and interleukin-6 (IL-6) [31] and also upregulates inflammatory molecules like vascular cell adhesion molecule-1 (VCAM-1), intercellular adhesion molecule1 (ICAM-1), and nuclear factor-kappa B (NF- $\kappa$ B) [31], which leads to degeneration of neurons results in diabetic encephalopathy.

Chronic inflammation is involved in the pathogenesis of several diseases such as insulin resistance, type 2 diabetes mellitus (T2DM), and cardiovascular diseases (CVD); obesity related chronic inflammation factors are described in Figure 1. Inflammation itself cannot be viewed as a disease but should be rather viewed as a biological process. Cotreatment routine significantly decreased the TBARS concentration and DNA fragmentation in the lungs [32].

Study was conducted to test the effect of lemon verbena extract on triglyceride accumulation in the insulin resistant hypertrophic 3T3-L1 cells adipocyte model. Lemon verbena 
polyphenols decreased the triglyceride accumulation and the ROS generation in hypertrophic adipocytes [33].

\section{Bioavailability of Polyphenols}

Briefly, polyphenols are natural compounds but synthetic and semisynthetic compounds are also available and characterized by the presence of phenolic structural units. Fruits, vegetables, cereals, and beverages are examples of dietary compounds containing polyphenols. More precisely, fruits such as grapes, apple, pear, cherries, and berries and their byproducts contain polyphenols. Moreover, red wine, tea or coffee, chocolates, cereals, and dry legumes also contain polyphenol [34]. Lastly, polyphenols are present in herbs, spices, stems, and flowers. In many countries, polyphenols are daily consumed as part of the diet [35]. Polyphenols are abundant antioxidants in some components of the diet. Daily intake of these dietary compounds may be as high as $1 \mathrm{~g} / \mathrm{d}$. Thus, polyphenols are generally higher in food than all other phytochemicals dietary antioxidants [36].

Polyphenols are the secondary metabolites of plants involved in defensive system by including protection from ultraviolet radiation and pathogens [37]. Polyphenols are characterized by bitterness, astringent color, odor, and protection against oxidative processes. To date, more than 8000 phenolic compounds have been identified in the plants. Examples of polyphenols are flavonoids such as flavonols, flavones, isoflavones, anthocyanidins, resveratrol, curcumin, tannins, lignans, and phenolic acids [38]. Polyphenols have some anti-inflammatory and antibiotic properties and may in addition activate the transcription factor Nrf2. Nrf2 plays a key role in cellular protection against oxidative stress and inflammation [39].

Environmental factors have major effect on the dietary polyphenol contents. These factors are type of the soil, exposure of the light, rainfall, culture methods, and fruit yield per tree. Flavonoid concentrations also depend on light exposure. Ripening process decreases or increases the concentration of some phenolic acids [40]. Bioavailability depends on numerous parameters including digestion, absorption, and metabolism. There are no simple relations between quantity of polyphenol and its bioavailability in human diet. Most polyphenols are present in the form of esters [41]. Polyphenols are poorly absorbed from intestine; polyphenols are firstly hydrolyzed by intestinal enzymes or by colonic microflora and then are absorbed. After being modified in different metabolic pathways, they finally come in the blood but not in the initial biological form [41]. Due to its incomplete absorption, polyphenols may reach the colon, where they are metabolized by the intestinal microbiota giving rise to several bacterial metabolites. Micromolar amounts of flavonoids and monophenols are recovered in the feces [42].

\section{Polyphenols on Oxidative Stress}

4.1. Antioxidant Properties of Polyphenols. The excessive production of ROS may cause tissue injury that may lead to the inflammatory process [43]. Polyphenol antioxidant activity depends on the structure of their functional groups. The number of hydroxyl groups greatly influences several mechanisms of antioxidant activity such as scavenging radicals and metal ion chelation ability [44]. Polyphenol antioxidant activities are related to their capacity to scavenge a wide range of ROS. Indeed, the mechanisms involved in the antioxidant capacity of polyphenols include suppression of ROS formation by either inhibition of enzymes involved in their production, scavenging of ROS, or upregulation or protection of antioxidant defenses [45].

Polyphenols may reduce the catalytic activity of enzymes involved in ROS generation. Polyphenols are able to protect against oxidative damage through various mechanisms [46]. ROS formation has been reported to enhance free metal ions by reduction of hydrogen peroxidase with generation of the highly reactive hydroxyl radical. Lower redox potentials of the polyphenols are thermodynamically able to reduce highly oxidizing free radicals because of their capacity to chelate metal ions (irons, copper, etc.) and free radical [47]. For instance, quercetin has iron chelating and iron-stabilizing properties.

4.2. Interaction of Free Radicals with Polyphenols. Polyphenols may react in plasma membrane with nonpolar compounds present in the hydrophobic inner membrane layer; such changes in the membrane may affect oxidation rate of lipid or proteins. Some flavonoids in the hydrophobic core of membrane may prevent access of oxidants and protect the structure and function of membrane [48]. These processes may help to understand the basic mechanisms of action of polyphenols including cellular interaction and signal transduction.

Interaction of polyphenols with nitric oxide synthases (NOS) activity may modulate the NO production. Xanthine oxidase $(\mathrm{XO})$ is considered as a key source of free radicals, and some flavonoids such as quercetin, silibin, and luteolin have been shown to inhibit such activity. Flavonoids may also reduce the activity of peroxidase and may inhibit the release of free radicals by neutrophils and activation of these cells by $\alpha 1$-antitrypsin [49].

4.3. Inhibition of Enzymes Involved in Oxidation. Various investigations have shown that different polyphenols modulate the activity of arachidonic acid metabolizing enzymes such as cyclooxygenase (COX), lipoxygenase (LOX), and NOS [50]. Inhibition of these enzymes reduces the production of AA, prostaglandins, leukotrienes, and $\mathrm{NO}$ which are among the key mediators of inflammation. Arachidonic acid pathway of inflammation is shown in Figure 2.

Bacterial endotoxins and inflammatory cytokines may stimulate macrophages with resulting increased iNOS expression and NO production and subsequent oxidative injury. Polyphenols may inhibit LPS-induced iNOS gene expression and its associated activity in cultured macrophages [51], thus resulting in decreased oxidative damage.

COX and LOX are the enzymatic activities responsible for the production of metabolites with capacity to increase the oxidative lesion in tissues. Some polyphenols have properties to inhibit the activities of COX and LOX [52]. Oxidative injury to the tissues may be worsened by metabolites notably 


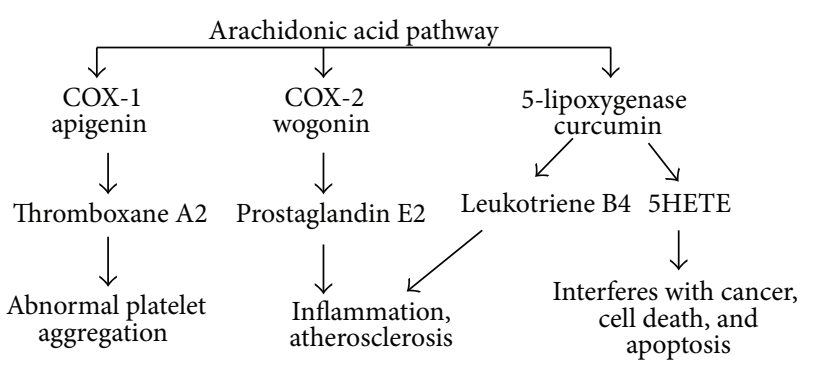

FIGURE 2: Metabolic pathways involved in arachidonic acid metabolism leading to inflammatory diseases.

those produced in the XO pathway. Xanthine dehydrogenase $(\mathrm{XDH})$ activity may convert into $\mathrm{XO}$ activity during the ischemia, resulting in the production of ROS. Deceased oxidative injury has been reported with polyphenols thus reducing the activity of $\mathrm{XO}$ [53].

\section{Polyphenols on Inflammation}

5.1. Modulatory Functions of Polyphenols towards Cells Involved in the Inflammatory Process. Anti-inflammatory activities of the polyphenols such as quercetin, rutin, morin, hesperetin, and hesperidin have been reported in acute and chronic inflammation in animal models (Table 1). Rutin is only effective in the chronic inflammatory processes especially in arthritis; and flavanones are also effective in neurogenic inflammation induced by xylene [54]. Quercetin has been reported to reduce paw edema induced by carrageenan. Paradkar et al., 2004 [55], reported that inflammatory reaction induced by LPS injection can be modulated with daidzin, glycitin, genistein, and their glucosides.

Polyphenols may affect enzymatic and signaling systems which are involved in the inflammatory processes, such as tyrosine and serine-threonine protein kinases. These enzymes are known to be involved in cell activation processes such as $\mathrm{T}$ cell proliferation, B lymphocyte activation [56], or cytokine production by stimulated monocytes. Genistein has been reported as a specific inhibitor for tyrosine protein kinase [57]. This latter compound may be involved in some of anti-inflammatory effects, since $\mathrm{T}$ cell proliferation is accompanied by phosphorylation of tyrosine of particular proteins. Polyphenols also exhibit an effect on secretory processes of inflammatory cells. Indeed, compounds such as luteolin, kaempferol, apigenin, or quercetin have been documented to represent powerful inhibitors of b-glucuronidase and lysozyme released from neutrophils. These polyphenols in addition significantly inhibit arachidonic acid release from cell membranes [58].

5.2. Mechanism of Anti-Inflammatory Effects of Polyphenols. Polyphenols may exert anti-inflammatory effects notably through radical scavenging activities, regulation of cellular activities in inflammatory cells, and modulation of the activities of enzymes involved in arachidonic acid metabolism (phospholipase A2, COX) and arginine metabolism (NOS), as well as the modulation of the production of other proinflammatory molecules.
Molecular mechanisms of polyphenol anti-inflammatory activities include inhibition of enzymes associated with proinflammatory properties such as COX-2, LOX, and iNOS, inhibition of NF- $\kappa \mathrm{B}$ and the activating protein-1 (AP-1), activation of phase-II antioxidant detoxifying enzymes, and activation of mitogen activated protein kinase (MAPK), protein kinase-C, and nuclear factor erythroid 2-related factor [59].

Strong evidences are originating from experiments with natural phytochemicals which have been shown to modulate different inflammatory mediators such as metabolites derived from arachidonic acid, various peptides, excitatory amino acids, and cytokines. Furthermore, activities of some second messengers (cGMP, cAMP, protein kinases, and calcium), some transcription factors (AP-1, NF- $\kappa \mathrm{B}$, and protooncogenes), and some enzymes and compounds (iNOS, COX-2), cytokines (IL-1 $\beta$, TNF- $\alpha$ ), neuropeptides, and proteases [22] are known to be central in the process of inflammation.

\section{The Roles of Polyphenols in Inflammation-Mediated Chronic Disorder}

6.1. Polyphenols and Cardiovascular Disease. Antioxidant properties of the polyphenols may be beneficial in the process of inflammation and in inflammation induced carcinogenesis [60, 61]. Many epidemiological and human studies have proposed that daily intake of polyphenols rich diet such as fruits, vegetables, cocoa, tea, and wine may exhibit fruitful effects in humans [62, 63]. Moreover, the meta-analysis studies suggested that higher intake of three cups of tea per day suppress risks by $11 \%$ [64] whereas adequate intake of red wine is related to $32 \%$ lower risk of cardiovascular disease (CVD) [65]. Although the active role of flavonoids in connection with CVD needs to be debated, in fact, systematic review on soy and cocoa flavonoids exerts health beneficial effects on preventing the risk of CVD [66]. The mechanism of polyphenols on vascular function depends on the ability of nitric oxide synthase (eNOS) and its bioavailability to the endothelium $[67,68]$. This vascular nitric oxide regularity mechanism is believed to have involvement of polyphenols with kinase molecular signaling like PI3-kinase/Akt pathway and intracellular $\mathrm{Ca}^{2+}$ on eNOS phosphorylation which ultimately results in NO production $[69,70]$. Flavanols and flavonols also can interact and lower the occurrences of age-related vascular injury [71] with interaction of MAPK signaling [72] and downregulation of transcription factors (i.e., NF-kB) which causes the reduction in nicotinamide adenine dinucleotide phosphate (NADPH) oxidase [73].

6.2. Polyphenols and Neurological Diseases. The dietary modulation of neurological diseases with polyphenols has been reported widely $[74,75]$. In addition, daily consumption of high flavonoids diet/beverages can reduce 50\% lowering the incidences of dementia [76] and aging [77] and may possibly delay the onset of Alzheimer's disease [78] and also reduce the occurrences of Parkinson's disease [79]. The protective mechanism of polyphenols on neurodegenerative diseases is to modulate neuronal and glial signaling 
TABLE 1: Anti-inflammatory activities of some polyphenolic compounds.

\begin{tabular}{|c|c|c|c|c|}
\hline $\begin{array}{l}\text { Phenolic } \\
\text { compounds }\end{array}$ & $\begin{array}{c}\text { Anti-inflammatory } \\
\text { activities }\end{array}$ & Inflammatory markers & Mechanism & References \\
\hline Apigenin & $\begin{array}{l}\text { Inhibiting LPS-induced } \\
\text { inflammation }\end{array}$ & Casp-1, IL-1 $\beta$ & $\begin{array}{c}\text { Inhibiting NLRP3 } \\
\text { inflammasome } \\
\text { activation }\end{array}$ & $\begin{array}{l}\text { Zhang et al., } \\
2014 \text { [8] }\end{array}$ \\
\hline Catechin & $\begin{array}{l}\text { Against monosodium } \\
\text { urate-induced } \\
\text { inflammation }\end{array}$ & IL-1 $\beta$ & $\begin{array}{l}\text { Modulating } \\
\text { NLRP3 } \\
\text { inflammasome } \\
\text { activation }\end{array}$ & $\begin{array}{l}\text { Jhang et al., } \\
2015 \text { [9] }\end{array}$ \\
\hline $\begin{array}{l}\text { Epigallocatechin } \\
\text { gallate }\end{array}$ & $\begin{array}{l}\text { Suppressing melanoma } \\
\text { growth }\end{array}$ & NLRP1, IL-1 $\beta$, NF $\kappa B$ & $\begin{array}{c}\text { Inhibiting NLRP3 } \\
\text { activation }\end{array}$ & $\begin{array}{l}\text { Ellis et al., } \\
2011[10]\end{array}$ \\
\hline $\begin{array}{l}\text { Epigallocatechin } \\
\text { gallate }\end{array}$ & $\begin{array}{l}\text { Protecting endothelial } \\
\text { cells against PCB } 126 \\
\text { induced inflammation }\end{array}$ & $\begin{array}{l}\text { GST, NQO1, MCP-1, } \\
\text { ICAM-1 }\end{array}$ & $\begin{array}{c}\text { Modulating } \\
\text { AhR/Nrf2 pathway }\end{array}$ & $\begin{array}{l}\text { Han et al., } \\
2012[11]\end{array}$ \\
\hline Ellagic acid & $\begin{array}{c}\text { Ameliorating } \\
\text { monocrotaline-induced } \\
\text { pulmonary artery } \\
\text { hypertension }\end{array}$ & $\begin{array}{l}\text { IL-1 } \beta, \text { IL-2, IL- } 4, \text { IL- } \\
\text { 6, IL-10, IFN- } \gamma, \\
\text { MIP-1, MDA, } \\
\text { NLPR3 }\end{array}$ & $\begin{array}{l}\text { Suppressing } \\
\text { NLRP3 } \\
\text { inflammasome } \\
\text { activation }\end{array}$ & $\begin{array}{l}\text { Tang et al., } \\
2015 \text { [12] }\end{array}$ \\
\hline Green tea & $\begin{array}{c}\text { Decreasing PCB } 126 \\
\text { induced oxidative stress }\end{array}$ & $\begin{array}{l}\text { SOD1, GSR, NQO1, } \\
\text { GST }\end{array}$ & $\begin{array}{c}\text { Stimulating } \\
\text { AhR/Nrf2 pathway }\end{array}$ & $\begin{array}{l}\text { Newsome et } \\
\text { al., } 2014 \text { [13] }\end{array}$ \\
\hline Homoplantaginin & $\begin{array}{l}\text { Inhibiting palmitic } \\
\text { acid-induced } \\
\text { inflammation }\end{array}$ & $\begin{array}{l}\text { IL-1 } \beta \text {, ICAM-1, } \\
\text { MCP-1, Casp-1 }\end{array}$ & $\begin{array}{l}\text { Interacting with } \\
\text { ROS sensitive } \\
\text { thioredoxin } \\
\text { protein }\end{array}$ & $\begin{array}{c}\text { He et al., } 2016 \\
{[14]}\end{array}$ \\
\hline Luteoloside & $\begin{array}{c}\text { Inhibiting proliferation, } \\
\text { invasion, and metastasis } \\
\text { of HCC cells }\end{array}$ & $\begin{array}{c}\text { ROS, NLPR3, Casp- } \\
\text { 1, IL- } 1 \beta\end{array}$ & $\begin{array}{l}\text { Suppressing } \\
\text { NLRP3 } \\
\text { inflammasome } \\
\text { activation }\end{array}$ & $\begin{array}{c}\text { Fan et al., } 2014 \\
{[15]}\end{array}$ \\
\hline Plant polyphenols & $\begin{array}{l}\text { Modulating the } \\
\text { inflammatory response } \\
\text { of human keratinocytes }\end{array}$ & $\begin{array}{l}\text { MCP-1, IL-10, IL-8, } \\
\text { TNF- } \alpha, \text { IL-6 }\end{array}$ & $\begin{array}{l}\text { Impairing } \\
\text { phosphorylation } \\
\text { EGF induced } \\
\text { NF } \kappa \text { B via } \\
\text { regulating AhR } \\
\text { signaling }\end{array}$ & $\begin{array}{l}\text { Potapovich et al., } \\
2011[16]\end{array}$ \\
\hline $\begin{array}{l}\text { Quercetin and } \\
\text { allopurinol }\end{array}$ & Repair of kidney injury & IL-1 $\beta$, IL-18 & $\begin{array}{l}\text { Suppressing } \\
\text { NLRP3 } \\
\text { inflammasomes }\end{array}$ & $\begin{array}{l}\text { Wang et al., } \\
2012 \text { [17] }\end{array}$ \\
\hline Resveratrol & $\begin{array}{l}\text { Ameliorating hepatic } \\
\text { metaflammation }\end{array}$ & IL-1, TNF- $\alpha$, IL-6 & $\begin{array}{l}\text { Inhibiting NLRP3 } \\
\text { activation }\end{array}$ & $\begin{array}{l}\text { Yang and Lim } \\
2014[18]\end{array}$ \\
\hline Rutin & $\begin{array}{l}\text { Reducing inflammation } \\
\text { in pancreas }\end{array}$ & $\begin{array}{l}\text { Casp-1, IL-1 } \beta \text {, ASC- } \\
\text { NLRP3, IL-18, TNF- } \alpha\end{array}$ & $\begin{array}{l}\text { Suppressing } \\
\text { NLRP3 } \\
\text { inflammasome } \\
\text { activation }\end{array}$ & $\begin{array}{l}\text { Aruna et al., } \\
2014 \text { [19] }\end{array}$ \\
\hline Tangeretin & $\begin{array}{l}\text { Attenuating oxidative } \\
\text { stress and protecting } \\
\text { hepatocellular } \\
\text { architecture }\end{array}$ & $\begin{array}{c}\text { CYP1B1, CYP2E1, } \\
\text { g-GCS, NQO1, HO-1, } \\
\text { IL-6, TNF- } \alpha \text {, IL-1 } \beta\end{array}$ & $\begin{array}{c}\text { Stimulating } \\
\text { AhR/Nrf2-Keap1 } \\
\text { pathway }\end{array}$ & $\begin{array}{c}\text { Arivazhagan and } \\
\text { Subramanian } 2015 \\
{[20]}\end{array}$ \\
\hline
\end{tabular}

LPS: lipopolysaccharide; Casp-1: caspase-1; IL: interleukin; NLRP: NOD-like receptor protein; NF- $\kappa$ B: nuclear factor-kappa B; GST: glutathione S-transferase; NQO1 (NAD(P)H: quinone oxidoreductase 1); MCP-1: monocyte chemotactic protein-1; ICAM-1: intercellular adhesion molecule-1; AhR: aryl hydrocarbon receptor; IFN- $\gamma$ : interferon-gamma; MIP-1: macrophage inflammatory protein-1; MDA: malondialdehyde; PCB: polychlorinated biphenyls; SOD: superoxide dismutase; GSR: glutathione S-reductase; GST: glutathione S-transferase; HCC: hepatocellular carcinoma cells; ROS: oxygen reactive species; TNF- $\alpha$ : tumor necrosis factor-alpha; EGF: epidermal growth factor; ASC: apoptosis associated speck-like CARD containing protein; CYPs, cytochrome P450 dependent monooxygenases; g-GCS: glutamate-cysteine ligase; HO-1: heme oxygenase-1.

pathways [80]. Polyphenols may downregulate transcription factors $\mathrm{NF}-\kappa \mathrm{B}[81,82]$, which react to p38 signaling and are responsible for iNOS induction [83]. It indicates that there might be a link in signaling pathways and transcription factors and cytokine production in exploring the neuroinflammation response in central nervous system. Furthermore, the ability of polyphenols on neuronal signaling exerts the defense in response to neurotoxicity induced by advanced glycation end products (AGEs) [84]. 
6.3. Polyphenols as an Alternative Target for Cancer Therapy. The literature revealed that intuitional supplementation of polyphenols decreases the incidences of different forms of cancer [85]. Polyphenols exert protection against gastrointestinal tract cancers whereas variety of polyphenols in fruits and vegetables are responsible for preventing the incidences of colon cancer [86]. Intake of green tea has been suggested to lower the incidences of biliary tract [87], bladder [88], breast [89], and colon cancer, respectively [90]. Polyphenols may possess anticancer activities by several mechanisms, comprising the elimination of carcinogenic agents [91], modifying cancer cell signaling [92] and cell cycle progression [93], progression of apoptosis [94], and modulation of enzymatic activities [95]. Polyphenols have shown antioxidant properties in tea, red wine, and cocoa, fruit, juices, and olive oil which suppresses cancer formation and development [96], such as interaction with reactive intermediates [97], and stimulates carcinogenesis and mutagens [98]. The compounds in green tea especially flavanol, epigallocatechin gallate (EGCG), possess anticancer properties via apoptotic induction and prevent cell growth by interference with cell cycle regulatory proteins and signaling proteins which are involved in cell proliferation, transformation, and metastasis [92].

\section{Conclusion and Perspectives}

Polyphenols are compounds with various potential biological properties such as antioxidants, anti-inflammatory, antineoplastic, antiaging, cardioprotective, anticancer, and antimicrobial properties. Polyphenols are gaining interest due to their wide applications in different pathological situations.

Oxidative stress activates a variety of inflammatory mediators involved in several chronic diseases. Clinical evidence suggests that oxidative stress and inflammation linked to overproduction of ROS are likely to represent an important component for the development of several diseases including inflammation-associated chronic diseases. Numerous studies performed with animal and cell models suggest that polyphenol dietary intake may be beneficial as adjuvant treatment for the prevention and treatment among such diseases. However, only few clinical studies, notably those done in a doubleblind manner, have been performed in order to establish the relevance of these experimental studies for extrapolation to human beings.

A better clarification and understanding of the mechanisms presumably involved in the protective role of polyphenols in adverse situations will help to more precisely define the clinical situations where polyphenol consumption will prove to be beneficial. Such investigation may in addition prove to be useful for the development of new compounds with anti-inflammatory effects.

\section{Competing Interests}

The authors declare no conflict of interests.

\section{Acknowledgments}

This work was supported the National Natural Science Foundation of China (nos. 31330075, 31560640, 31372326,
31672433, and 31301989), the National Science and Technology Ministry (2014BAD08B11), and the Science and Technology Department of Hunan Province (2015JC3126). The authors are also thankful to CAS-TWAS President's Fellowship and UCAS financial and infrastructure support, as well as Changsha Lvye Biotechnology Limited Company Academician Expert Workstation.

\section{References}

[1] Z. Ďuračková, "Some current insights into oxidative stress," Physiological Research, vol. 59, no. 4, pp. 459-469, 2010.

[2] S. Kumar and A. K. Pandey, "Free radicals: health implications and their mitigation by herbals," British Journal of Medicine and Medical Research, vol. 7, no. 6, pp. 438-457, 2015.

[3] V. Goossens, K. De Vos, D. Vercammen et al., "Redox regulation of TNF signaling," BioFactors, vol. 10, no. 2-3, pp. 145-156, 1999.

[4] R. O. Poyton, K. A. Ball, and P. R. Castello, "Mitochondrial generation of free radicals and hypoxic signaling," Trends in Endocrinology and Metabolism, vol. 20, no. 7, pp. 332-340, 2009.

[5] S. P. Hussain, L. J. Hofseth, and C. C. Harris, "Radical causes of cancer," Nature Reviews Cancer, vol. 3, no. 4, pp. 276-285, 2003.

[6] C.-H. Chang, F.-Y. Yu, T.-S. Wu, L.-T. Wang, and B.-H. Liu, "Mycotoxin citrinin induced cell cycle G2/M arrest and numerical chromosomal aberration associated with disruption of microtubule formation in human cells," Toxicological Sciences, vol. 119, no. 1, pp. 84-92, 2011.

[7] C. Wang, G. B. Schuller Levis, E. B. Lee et al., "Platycodin D and D3 isolated from the root of Platycodon grandiflorum modulate the production of nitric oxide and secretion of TNF- $\alpha$ in activated RAW 264.7 cells," International Immunopharmacology, vol. 4, no. 8, pp. 1039-1049, 2004.

[8] X. Zhang, G. Wang, E. C. Gurley, and H. Zhou, "Flavonoid apigenin inhibits lipopolysaccharide-induced inflammatory response through multiple mechanisms in macrophages," PLoS ONE, vol. 9, no. 9, Article ID e107072, 2014.

[9] J.-J. Jhang, C.-C. Lu, C.-Y. Ho, Y.-T. Cheng, and G.-C. Yen, "Protective Effects of catechin against monosodium urateinduced inflammation through the modulation of NLRP3 inflammasome activation," Journal of Agricultural and Food Chemistry, vol. 63, no. 33, pp. 7343-7352, 2015.

[10] L. Z. Ellis, W. Liu, Y. Luo et al., "Green tea polyphenol epigallocatechin-3-gallate suppresses melanoma growth by inhibiting inflammasome and IL- $1 \beta$ secretion," Biochemical and Biophysical Research Communications, vol. 414, no. 3, pp. 551556, 2011.

[11] S. G. Han, S.-S. Han, M. Toborek, and B. Hennig, "EGCG protects endothelial cells against PCB 126-induced inflammation through inhibition of AhR and induction of Nrf2-regulated genes," Toxicology and Applied Pharmacology, vol. 261, no. 2, pp. 181-188, 2012.

[12] B. Tang, G.-X. Chen, M.-Y. Liang, J.-P. Yao, and Z.-K. $\mathrm{Wu}$, "Ellagic acid prevents monocrotaline-induced pulmonary artery hypertension via inhibiting NLRP3 inflammasome activation in rats," International Journal of Cardiology, vol. 180, pp. 134-141, 2015.

[13] B. J. Newsome, M. C. Petriello, S. G. Han et al., "Green tea diet decreases PCB 126-induced oxidative stress in mice by up-regulating antioxidant enzymes," Journal of Nutritional Biochemistry, vol. 25, no. 2, pp. 126-135, 2014. 
[14] B. He, B. Zhang, F. Wu et al., "Homoplantaginin inhibits palmitic acid-induced endothelial cells inflammation by suppressing TLR4 and NLRP3 inflammasome," Journal of Cardiovascular Pharmacology, vol. 67, no. 1, pp. 93-101, 2016.

[15] S.-H. Fan, Y.-Y. Wang, J. Lu et al., "Luteoloside suppresses proliferation and metastasis of hepatocellular carcinoma cells by inhibition of NLRP3 inflammasome," PLoS ONE, vol. 9, no. 2, Article ID e89961, 2014.

[16] A. I. Potapovich, D. Lulli, P. Fidanza et al., "Plant polyphenols differentially modulate inflammatory responses of human keratinocytes by interfering with activation of transcription factors NFkB and AhR and EGFR-ERK pathway," Toxicology and Applied Pharmacology, vol. 255, no. 2, pp. 138-149, 2011.

[17] C. Wang, Y. Pan, Q.-Y. Zhang, F.-M. Wang, and L.-D. Kong, "Quercetin and allopurinol ameliorate kidney injury in STZtreated rats with regulation of renal NLRP3 inflammasome activation and lipid accumulation," PLoS ONE, vol. 7, no. 6, article e38285, 2012.

[18] S. J. Yang and Y. Lim, "Resveratrol ameliorates hepatic metaflammation and inhibits NLRP3 inflammasome activation," Metabolism: Clinical and Experimental, vol. 63, no. 5, pp. 693-701, 2014.

[19] R. Aruna, A. Geetha, and P. Suguna, "Rutin modulates ASC expression in NLRP3 inflammasome: a study in alcohol and cerulein-induced rat model of pancreatitis," Molecular and Cellular Biochemistry, vol. 396, no. 1-2, pp. 269-280, 2014.

[20] L. Arivazhagan and S. P. Subramanian, "Tangeretin, a citrus flavonoid attenuates oxidative stress and protects hepatocellular architecture in rats with 7, 12-dimethylbenz (a) anthracene induced experimental mammary carcinoma," Journal of Functional Foods, vol. 15, pp. 339-353, 2015.

[21] S. Kumar and A. K. Pandey, "Chemistry and biological activities of flavonoids: an overview," The Scientific World Journal, vol. 2013, Article ID 162750, 16 pages, 2013.

[22] Y. S. Kim, M. R. Young, G. Bobe, N. H. Colburn, and J. A. Milner, "Bioactive food components, inflammatory targets, and cancer prevention," Cancer Prevention Research, vol. 2, no. 3, pp. $200-$ 208, 2009.

[23] B. S. Berlett and E. R. Stadtman, "Protein oxidation in aging, disease, and oxidative stress," Journal of Biological Chemistry, vol. 272, no. 33, pp. 20313-20316, 1997.

[24] S. Salzanoa, P. Checconia, E. M. Hanschmannc et al., "Linkage of inflammation and oxidative stress via release of glutathionylated peroxiredoxin-2, which acts as a danger signal," Proceeding of National Academy of Sciences of United States of America, vol. 111, no. 33, pp. 12157-12162, 2014.

[25] A. Popa-Wagner, S. Mitran, S. Sivanesan, E. Chang, and A.-M. Buga, "ROS and brain diseases: the good, the bad, and the ugly," Oxidative Medicine and Cellular Longevity, vol. 2013, Article ID 963520, 14 pages, 2013.

[26] P. Ghezzi, "Role of glutathione in immunity and inflammation in the lung," International Journal of General Medicine, vol. 4, pp. 105-113, 2011.

[27] P. Ghezzi, "Protein glutathionylation in health and disease," Biochimica et Biophysica Acta-General Subjects, vol. 1830, no. 5, pp. 3165-3172, 2013.

[28] M. Fratelli, H. Demol, M. Puype et al., "Identification by redox proteomics of glutathionylated proteins in oxidatively stressed human T lymphocytes," Proceedings of the National Academy of Sciences of the United States of America, vol. 99, no. 6, pp. 35053510, 2002.
[29] L. P. Reagan, A. M. Magariños, and B. S. McEwen, "Neurological changes induced by stress in streptozotocin diabetic rats," Annals of the New York Academy of Sciences, vol. 893, pp. 126137, 1999.

[30] A. Acar, E. Akil, H. Alp et al., "Oxidative damage is ameliorated by curcumin treatment in brain and sciatic nerve of diabetic rats," International Journal of Neuroscience, vol. 122, no. 7, pp. 367-372, 2012.

[31] O. Prabhakar, "Cerebroprotective effect of resveratrol through antioxidant and anti-inflammatory effects in diabetic rats," Naunyn-Schmiedeberg's Archives of Pharmacology, vol. 386, no. 8, pp. 705-710, 2013.

[32] R. A. Khan, "Protective effect of Launaea procumbens (L.) on lungs against $\mathrm{CCl}_{4}$-induced pulmonary damages in rat," $B M C$ Complementary and Alternative Medicine, vol. 12, article 133, 2012.

[33] M. Herranz-López, E. Barrajón-Catalán, A. Segura-Carretero, J. A. Menéndez, J. Joven, and V. Micol, "Lemon verbena (Lippia citriodora) polyphenols alleviate obesity-related disturbances in hypertrophic adipocytes through AMPK-dependent mechanisms," Phytomedicine, vol. 22, no. 6, pp. 605-614, 2015.

[34] J. P. E. Spencer, M. M. Abd El Mohsen, A.-M. Minihane, and J. C. Mathers, "Biomarkers of the intake of dietary polyphenols: strengths, limitations and application in nutrition research," British Journal of Nutrition, vol. 99, no. 1, pp. 12-22, 2008.

[35] G. R. Beecher, "Overview of dietary flavonoids: nomenclature, occurrence and intake," Journal of Nutrition, vol. 133, no. 10, pp. 3248S-3254S, 2003.

[36] C. Manach, A. Scalbert, C. Morand, C. Rémésy, and L. Jiménez, "Polyphenols: food sources and bioavailability," The American Journal of Clinical Nutrition, vol. 79, no. 5, pp. 727-747, 2004.

[37] K. B. Pandey and S. I. Rizvi, "Plant polyphenols as dietary antioxidants in human health and disease," Oxidative Medicine and Cellular Longevity, vol. 2, no. 5, pp. 270-278, 2009.

[38] S. Tanigawa, M. Fujii, and D.-X. Hou, "Action of Nrf2 and Keap1 in ARE-mediated NQO1 expression by quercetin," Free Radical Biology and Medicine, vol. 42, no. 11, pp. 1690-1703, 2007.

[39] L. F. M. F. Cardozo, L. M. Pedruzzi, P. Stenvinkel et al., "Nutritional strategies to modulate inflammation and oxidative stress pathways via activation of the master antioxidant switch Nrf2," Biochimie, vol. 95, no. 8, pp. 1525-1533, 2013.

[40] J. J. Macheix, A. Fleuriet, and J. Billot, Fruit Phenolics, CRC Press, Boca Raton, Fla, USA, 1990.

[41] M. D’Archivio, C. Filesi, R. Di Benedetto, R. Gargiulo, C. Giovannini, and R. Masella, "Polyphenols, dietary sources and bioavailability," Annali dell'Istituto Superiore di Sanità, vol. 43, no. 4, pp. 348-361, 2007.

[42] S. Possemiers, S. Bolca, W. Verstraete, and A. Heyerick, "The intestinal microbiome: a separate organ inside the body with the metabolic potential to influence the bioactivity of botanicals," Fitoterapia, vol. 82, no. 1, pp. 53-66, 2011.

[43] J. K. Willcox, S. L. Ash, and G. L. Catignani, "Antioxidants and prevention of chronic disease," Critical Reviews in Food Science and Nutrition, vol. 44, no. 4, pp. 275-295, 2004.

[44] K. E. Heim, A. R. Tagliaferro, and D. J. Bobilya, "Flavonoid antioxidants: chemistry, metabolism and structure-activity relationships," Journal of Nutritional Biochemistry, vol. 13, no. 10, pp. 572-584, 2002.

[45] A. Mishra, A. K. Sharma, S. Kumar, A. K. Saxena, and A. K. Pandey, "Bauhinia variegata leaf extracts exhibit considerable antibacterial, antioxidant, and anticancer activities," BioMed 
Research International, vol. 2013, Article ID 915436, 10 pages, 2013.

[46] S. Kumar, U. K. Sharma, A. K. Sharma, and A. K. Pandey, "Protective efficacy of Solanum xanthocarpum root extracts against free radical damage: phytochemical analysis and antioxidant effect," Cellular and Molecular Biology, vol. 58, no. 1, pp. 174-181, 2012.

[47] A. Mishra, S. Kumar, and A. K. Pandey, "Scientific validation of the medicinal efficacy of Tinospora cordifolia," The Scientific World Journal, vol. 2013, Article ID 292934, 8 pages, 2013.

[48] P. I. Oteiza, A. G. Erlejman, S. V. Verstraeten, C. L. Keen, and C. G. Fraga, "Flavonoid-membrane interactions: a protective role of flavonoids at the membrane surface?" Clinical and Developmental Immunology, vol. 12, no. 1, pp. 19-25, 2005.

[49] R. J. Nijveldt, E. van Nood, D. E. C. Van Hoorn, P. G. Boelens, K. van Norren, and P. A. M. van Leeuwen, "Flavonoids: a review of probable mechanisms of action and potential applications," American Journal of Clinical Nutrition, vol. 74, no. 4, pp. 418425, 2001.

[50] B. S. Cheon, Y. H. Kim, K. S. Son, H. W. Chang, S. S. Kang, and H. P. Kim, "Effects of prenylated flavonoids and biflavonoids on lipopolysaccharide-induced nitric oxide production from the mouse macrophage cell line RAW 264.7," Planta Medica, vol. 66, no. 7, pp. 596-600, 2000.

[51] A. Sarkar and A. Bhaduri, "Black tea is a powerful chemopreventor of reactive oxygen and nitrogen species: comparison with its individual catechin constituents and green tea," Biochemical and Biophysical Research Communications, vol. 284, no. 1, pp. 173-178, 2001.

[52] J. Hong, T. J. Smith, C.-T. Ho, D. A. August, and C. S. Yang, "Effects of purified green and black tea polyphenols on cyclooxygenase- and lipoxygenase-dependent metabolism of arachidonic acid in human colon mucosa and colon tumor tissues," Biochemical Pharmacology, vol. 62, no. 9, pp. 1175-1183, 2001.

[53] A. Nagao, M. Seki, and H. Kobayashi, "Inhibition of xanthine oxidase by flavonoids," Bioscience, Biotechnology and Biochemistry, vol. 63, no. 10, pp. 1787-1790, 1999.

[54] A. E. Rotelli, T. Guardia, A. O. Juárez, N. E. De La Rocha, and L. E. Pelzer, "Comparative study of flavonoids in experimental models of inflammation," Pharmacological Research, vol. 48, no. 6, pp. 601-606, 2003.

[55] P. N. Paradkar, P. S. Blum, M. A. Berhow, H. Baumann, and S.-M. Kuo, "Dietary isoflavones suppress endotoxin-induced inflammatory reaction in liver and intestine," Cancer Letters, vol. 215, no. 1, pp. 21-28, 2004.

[56] M. A. Campbell and C. M. Sefton, "Protein tyrosine phosphorylation is induced in murine B lymphocytes in response to stimulation with anti-immunoglobulin," European Molecular Biology Organization, Journal, vol. 9, no. 7, pp. 2125-2131, 1999.

[57] T. Akiyama, J. Ishida, S. Nakagawa et al., "Genistein, a specific inhibitor of tyrosine-specific protein kinases," The Journal of Biological Chemistry, vol. 262, no. 12, pp. 5592-5595, 1987.

[58] M. Tordera, M. L. Ferrandiz, and M. J. Alcaraz, "Influence of anti-inflammatory flavonoids on degranulation and arachidonic acid release in rat neutrophils," Zeitschrift fur Naturforschung Section C, vol. 49, no. 3-4, pp. 235-240, 1994.

[59] C. Santangelo, R. Varì, B. Scazzocchio, R. Di Benedetto, C. Filesi, and R. Masella, "Polyphenols, intracellular signalling and inflammation," Annali dell'Istituto Superiore di Sanita, vol. 43, no. 4, pp. 394-405, 2007.
[60] V. Sosa, T. Moliné, R. Somoza, R. Paciucci, H. E. Kondoh, and M. E. LLeonart, "Oxidative stress and cancer: an overview," Ageing Research Reviews, vol. 12, no. 1, pp. 376-390, 2013.

[61] M. Pollard and M. A. Suckow, "Dietary prevention of hormone refractory prostate cancer in Lobund-Wistar rats: a review of studies in a relevant animal model," Comparative Medicine, vol. 56, no. 6, pp. 461-467, 2006.

[62] I. C. W. Arts, D. R. Jacobs Jr., L. J. Harnack, M. Gross, and A. R. Folsom, "Dietary catechins in relation to coronary heart disease death among postmenopausal women," Epidemiology, vol. 12, no. 6, pp. 668-675, 2001.

[63] L. Yochum, L. H. Kushi, K. Meyer, and A. R. Folsom, "Dietary flavonoid intake and risk of cardiovascular disease in postmenopausal women," American Journal of Epidemiology, vol. 149, no. 10, pp. 943-949, 1999.

[64] U. Peters, C. Poole, and L. Arab, "Does tea affect cardiovascular disease? A meta-analysis," American Journal of Epidemiology, vol. 154, no. 6, pp. 495-503, 2001.

[65] A. Di Castelnuovo, S. Rotondo, L. Iacoviello, M. B. Donati, and G. De Gaetano, "Meta-analysis of wine and beer consumption in relation to vascular risk," Circulation, vol. 105, no. 24, pp. 28362844, 2002.

[66] L. Hooper, P. A. Kroon, E. B. Rimm et al., "Flavonoids, flavonoid-rich foods, and cardiovascular risk: a meta-analysis of randomized controlled trials," American Journal of Clinical Nutrition, vol. 88, no. 1, pp. 38-50, 2008.

[67] C. Heiss, A. Dejam, P. Kleinbongard, T. Schewe, H. Sies, and M. Kelm, "Vascular effects of cocoa rich in flavan-3-ols," The Journal of the American Medical Association, vol. 290, no. 8, pp. 1030-1031, 2003.

[68] M. M. Appeldoorn, D. P. Venema, T. H. F. Peters et al., "Some phenolic compounds increase the nitric oxide level in endothelial cells in vitro," Journal of Agricultural and Food Chemistry, vol. 57, no. 17, pp. 7693-7699, 2009.

[69] M. Lorenz, S. Wessler, E. Follmann et al., "Constituent of green tea, epigallocatechin-3-gallate, activates endothelial nitric oxide synthase by a phosphatidylinositol-3-OH-kinase-, cAMP-dependent protein kinase-, and Akt-dependent pathway and leads to endothelial-dependent vasorelaxation," Journal of Biological Chemistry, vol. 279, pp. 6190-6195, 2004.

[70] J.-C. Stoclet, T. Chataigneau, M. Ndiaye et al., "Vascular protection by dietary polyphenols," European Journal of Pharmacology, vol. 500, no. 1-3, pp. 299-313, 2004.

[71] M. Peppa and S. A. Raptis, "Advanced glycation end products and cardiovascular disease," Current Diabetes Reviews, vol. 4, no. 2, pp. 92-100, 2008.

[72] S.-M. Huang, C.-H. Wu, and G.-C. Yen, "Effects of flavonoids on the expression of the pro-inflammatory response in human monocytes induced by ligation of the receptor for AGEs," Molecular Nutrition and Food Research, vol. 50, no. 12, pp. 11291139, 2006.

[73] J. M. Kim, E. K. Lee, D. H. Kim, B. P. Yu, and H. Y. Chung, "Kaempferol modulates pro-inflammatory NF- $\kappa$ B activation by suppressing advanced glycation endproducts-induced NADPH oxidase," Age, vol. 32, no. 2, pp. 197-208, 2010.

[74] J. Lindsay, D. Laurin, R. Verreault et al., "Risk factors for Alzheimer's disease: a prospective analysis from the Canadian Study of Health and Aging," American Journal of Epidemiology, vol. 156, no. 5, pp. 445-453, 2002.

[75] T. Truelsen, D. Thudium, and M. Grønbæk, "Amount and type of alcohol and risk of dementia: the Copenhagen City Heart Study," Neurology, vol. 59, no. 9, pp. 1313-1319, 2002. 
[76] D. Commenges, V. Scotet, S. Renaud, H. Jacqmin-Gadda, P. Barberger-Gateau, and J.-F. Dartigues, "Intake of flavonoids and risk of dementia," European Journal of Epidemiology, vol. 16, no. 4, pp. 357-363, 2000.

[77] M. C. Morris, D. A. Evans, C. C. Tangney, J. L. Bienias, and R. S. Wilson, "Associations of vegetable and fruit consumption with age-related cognitive change," Neurology, vol. 67, no. 8, pp. 13701376, 2006.

[78] Q. Dai, A. R. Borenstein, Y. Wu, J. C. Jackson, and E. B. Larson, "Fruit and vegetable juices and Alzheimer's disease: The Kame Project," American Journal of Medicine, vol. 119, no. 9, pp. 751759, 2006.

[79] H. Checkoway, K. Powers, T. Smith-Weller, G. M. Franklin, W. T. Longstreth Jr., and P. D. Swanson, "Parkinson's disease risks associated with cigarette smoking, alcohol consumption, and caffeine intake," American Journal of Epidemiology, vol. 155, no. 8, pp. 732-738, 2002.

[80] D. Vauzour, K. Vafeiadou, C. Rice-Evans, R. J. Williams, and J. P. E. Spencer, "Activation of pro-survival Akt and ERK1/2 signalling pathways underlie the anti-apoptotic effects of flavanones in cortical neurons," Journal of Neurochemistry, vol. 103, no. 4, pp. 1355-1367, 2007.

[81] K. Vafeiadou, D. Vauzour, H. Y. Lee, A. Rodriguez-Mateos, R. J. Williams, and J. P. E. Spencer, "The citrus flavanone naringenin inhibits inflammatory signalling in glial cells and protects against neuroinflammatory injury," Archives of Biochemistry and Biophysics, vol. 484, no. 1, pp. 100-109, 2009.

[82] X. Wang, S. Chen, G. Ma, M. Ye, and G. Lu, "Genistein protects dopaminergic neurons by inhibiting microglial activation," NeuroReport, vol. 16, no. 3, pp. 267-270, 2005.

[83] N. R. Bhat, D. L. Feinstein, Q. Shen, and A. N. Bhat, "p38 MAPKmediated transcriptional activation of inducible nitric-oxide synthase in glial cells: roles of nuclear factors, nuclear factor $\kappa \mathrm{B}$, cAMP response element-binding protein, CCAAT/enhancerbinding protein- $\beta$, and activating transcription factor-2," The Journal of Biological Chemistry, vol. 277, no. 33, pp. 2958429592, 2002.

[84] S.-J. Lee and K.-W. Lee, "Protective effect of (-)-epigallocatechin gallate against advanced glycation endproducts-induced injury in neuronal cells," Biological and Pharmaceutical Bulletin, vol. 30, no. 8, pp. 1369-1373, 2007.

[85] S. Kuriyama, T. Shimazu, K. Ohmori et al., "Green tea consumption and mortality due to cardiovascular disease, cancer, and all causes in Japan, the Ohsaki study," The Journal of the American Medical Association, vol. 296, no. 10, pp. 1255-1265, 2006.

[86] M. E. Martínez, "Primary prevention of colorectal cancer: lifestyle, nutrition, exercise," Recent Results in Cancer Research, vol. 166, pp. 177-211, 2005.

[87] M. Takada, Y. Ku, K. Habara, T. Ajiki, Y. Suzuki, and Y. Kuroda, "Inhibitory effect of epigallocatechin-3-gallate on growth and invasion in human biliary tract carcinoma cells," World Journal of Surgery, vol. 26, no. 6, pp. 683-686, 2002.

[88] K. M. Rieger-Christ, R. Hanley, C. Lodowsky et al., "The green tea compound, (-)-epigallocatechin-3-gallate downregulates $\mathrm{N}$-cadherin and suppresses migration of bladder carcinoma cells," Journal of Cellular Biochemistry, vol. 102, no. 2, pp. 377388, 2007.

[89] H. Leong, P. S. Mathur, and G. L. Greene, "Inhibition of mammary tumorigenesis in the C3(1)/SV40 mouse model by green tea," Breast Cancer Research and Treatment, vol. 107, no. 3, pp. 359-369, 2008.
[90] C. A. Larsen and R. H. Dashwood, "Suppression of Met activation in human colon cancer cells treated with (-)epigallocatechin-3-gallate: minor role of hydrogen peroxide," Biochemical and Biophysical Research Communications, vol. 389, no. 3, pp. 527-530, 2009.

[91] R. W. Owen, A. Giacosa, W. E. Hull, R. Haubner, B. Spiegelhalder, and H. Bartsch, "The antioxidant/anticancer potential of phenolic compounds isolated from olive oil," European Journal of Cancer, vol. 36, no. 10, pp. 1235-1247, 2000.

[92] N. Khan, F. Afaq, M. Saleem, N. Ahmad, and H. Mukhtar, "Targeting multiple signaling pathways by green tea polyphenol (-)-epigallocatechin-3-gallate," Cancer Research, vol. 66, no. 5, pp. 2500-2505, 2006.

[93] G. Corona, M. Deiana, A. Incani, D. Vauzour, M. A. Dessià, and J. P. E. Spencer, "Hydroxytyrosol inhibits the proliferation of human colon adenocarcinoma cells through inhibition of ERK1/2 and cyclin D1," Molecular Nutrition and Food Research, vol. 53, no. 7, pp. 897-903, 2009.

[94] S. K. Mantena, M. S. Baliga, and S. K. Katiyar, "Grape seed proanthocyanidins induce apoptosis and inhibit metastasis of highly metastatic breast carcinoma cells," Carcinogenesis, vol. 27, no. 8, pp. 1682-1691, 2006.

[95] L. S. Adam and S. Chen, "Phytochemicals for breast cancer prevention by targeting aromatase," Frontiers in Bioscience, vol. 14, no. 10, pp. 3846-3863, 2009.

[96] E. Middleton, "Implications for inflammation, heart disease, and cancer," Pharmacological Reviews, vol. 52, pp. 673-751, 2000.

[97] S. J. Duthie and V. L. Dobson, "Dietary flavonoids protect human colonocyte DNA from oxidative attack in vitro," European Journal of Nutrition, vol. 38, no. 1, pp. 28-34, 1999.

[98] M. Calomme, L. Pieters, A. Vlietinck, and D. V. Berghe, "Inhibition of bacterial mutagenesis by Citrus flavonoids," Planta Medica, vol. 62, no. 3, pp. 222-226, 1996. 


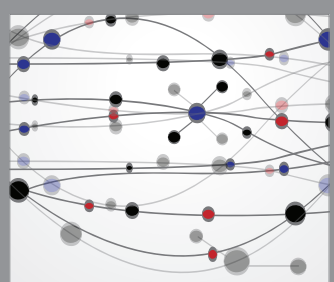

The Scientific World Journal
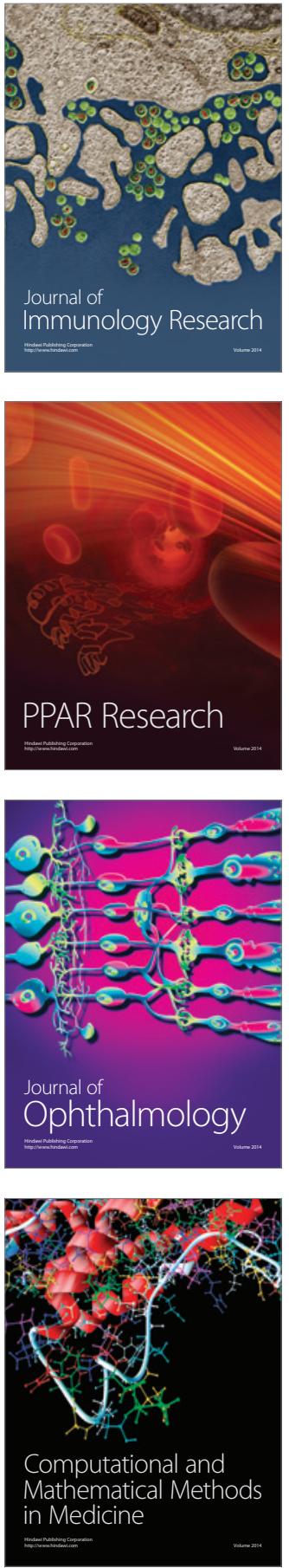

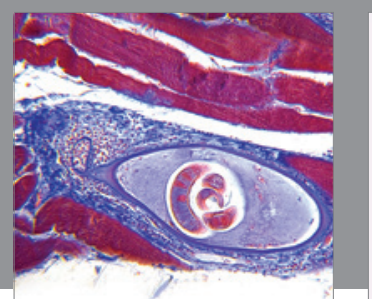

Gastroenterology Research and Practice

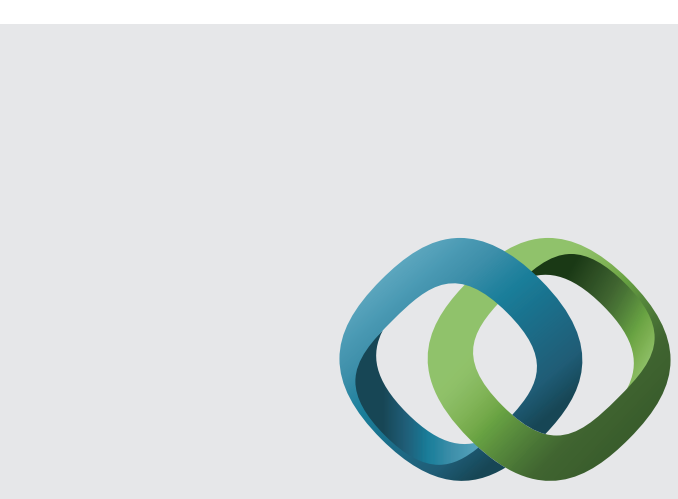

\section{Hindawi}

Submit your manuscripts at

http://www.hindawi.com
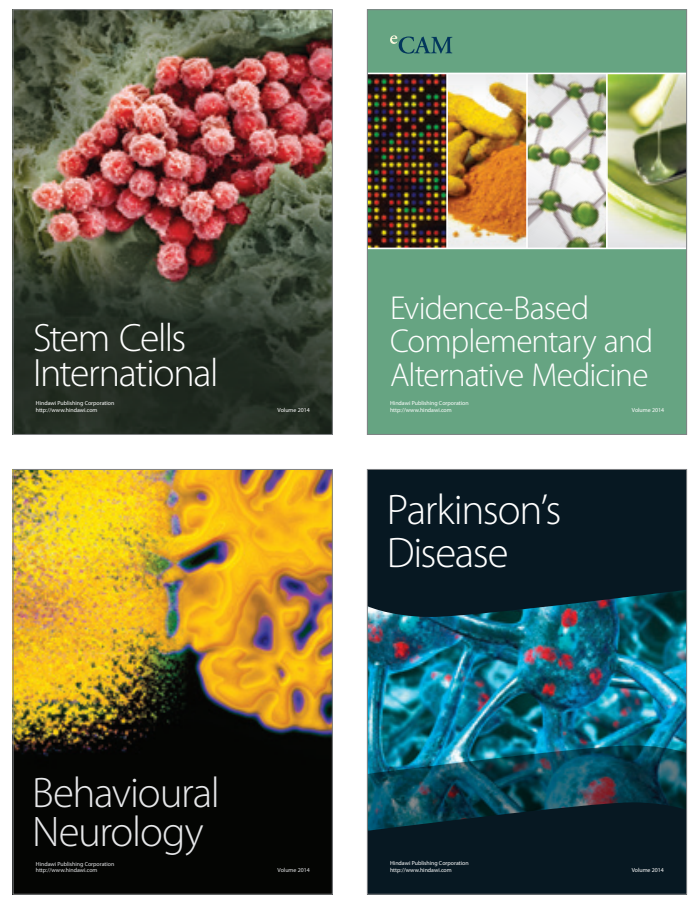
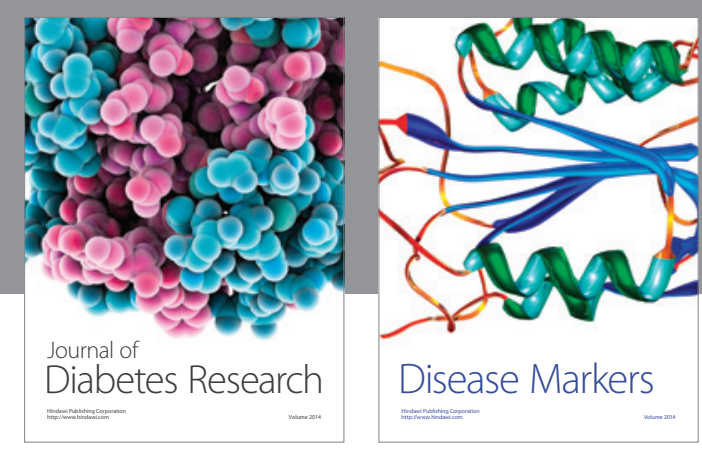

Disease Markers
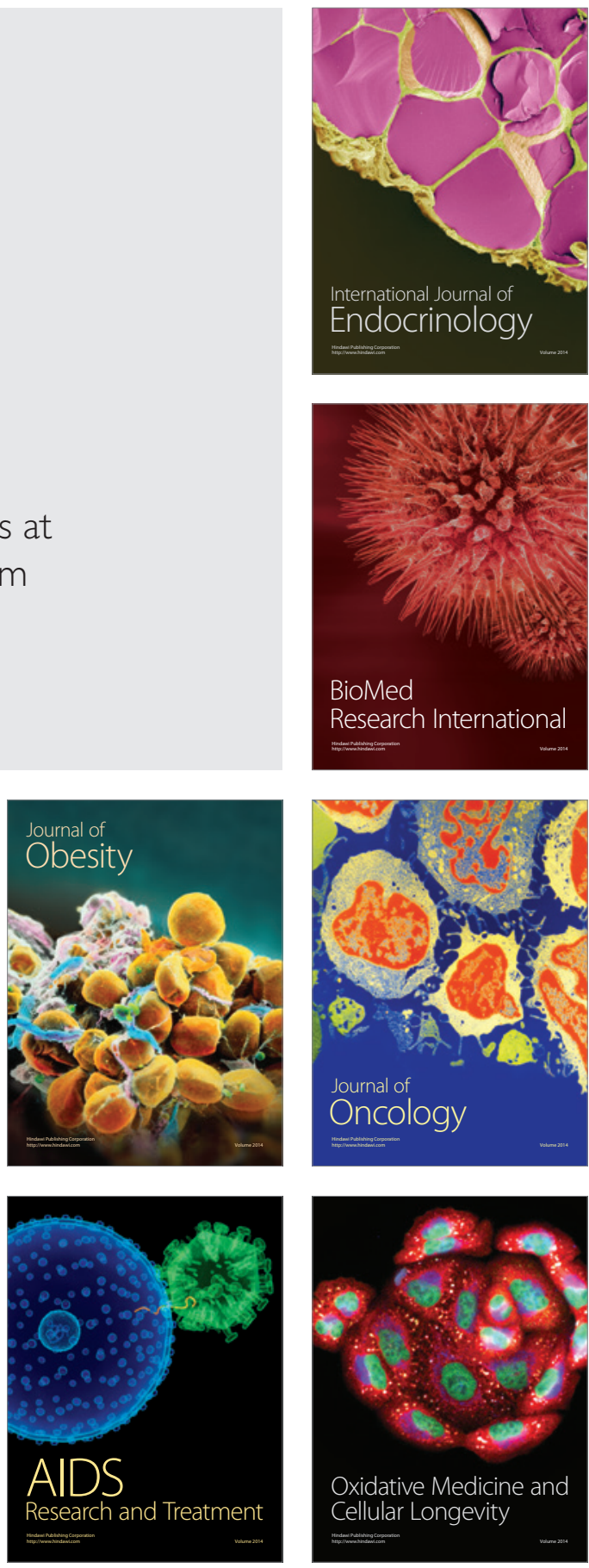